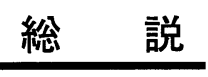

\title{
水素結合による液晶性分子複合体 構造制御とそのダイナミックな特徴の発現
}

\author{
加 藤 隆 史 \\ 東京大学生産技術研究所（テ106 東京都港区六本木 7-22-1）
}

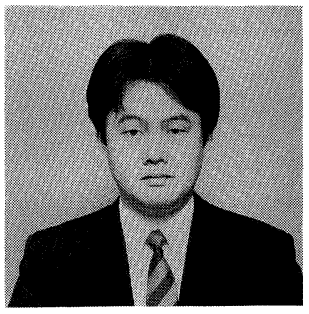
Hydrogen-Bonded Liquid-Crystalline Molecular Complexes
Structural Control and Induction of Dynamic Properties

Takashi KATO

Institute of Industrial Science, The University of Tokyo

(Roppongi, Minato-ku, Tokyo, T106)

\begin{abstract}
In the design of functional organic materials, it is important to use molecular interactions. Hydrogen bonding is one of the key interactions for molecular association and recognition in nature. Recently, new types of hydrogen-bonded liquid-crystalline (LC) complexes have been obtained by molecular recognition between complementary components. For example, molecular recognition by hydrogen bonds between carboxylic acid and pyridyl moieties results in the quantitative formation of well-defined structures of mesogens. In the hydrogen-bonded liquid crystals, dynamic nature of hydrogen bonding gives unique LC structures of complexes such as polymer networks, polymer alloys, and one-dimensional polymers. For LC polymer networks, stable liquid-crystalline phases have been induced by the formation of dynamic intermolecular mesogen consisting of polymer side chain and a small molecule. A wide variety of supramolecular mesogenic materials can be obtained by the molecular aggregation via various hydrogen bonds.
\end{abstract}

\section{1 水素結合による液晶性分子複合体の構築}

分子を集合させ, 秩序構造を構筑していくことは, 機 能材料をつくる上で非常に重要な課題である。この分子 集合プロセスには．相互作用の働きが一つのかぎ(鍵)を 握っている。自然界には様々な相互作用が存在してい $3^{1)}$ 。我々が, 人工系の機能性分子集合体をつくろうと するときは, この相互作用の特徴をよく理解して, 目的 に合わせて適切に活用できるような分子デザインを行っ ていくことが重要である。相互作用の中で水素結合 $は^{2)}$, 生体系において DNA・RNA における遺伝情報 伝達などいたるところで用いられている。したがって, その重要性は理解され, 溶液中における孤立分子系の水 素結合による分子認識システムの開発は進んでいる3

しかしながら, 液晶・結晶・高分子集合体などのよう な機能性分子凝集系においては, 水素結合の活用は, 進 んできたがまだ充分とはいえず，これからの分野といえ る4)。液晶においてはすでに, カルボン酸同士の水素結
合による安息香酸誘導体の二量体が液晶性を示すことが 数十年前から知られていた5)。しかし, この分子は常に 二量体構造をとっており, 基礎的に重要な知見を多く提 供してきたが, 水素結合の面白さが特に発揮されること はあまりなかった。また, いくつかの水素結合による液 晶の報告はあったが, どれも同種分子間の水素結合によ るものであり, 分子認識の観点からの液晶分子デザイン はなかった。

自然界での水素結合の強さの位置付けを下に示す。分 子ユニットをつなぐ分子間力としての結合エネルギーの 大きさは, 共有結合よりは 1 けた程度小さく, ファンデ アワールスカなどよりは 1 けた大きい程度である。すな わち比較的強い相互作用ということができる。方向性が あることが大きな特徴で, これが様々な異分子間の特異 的認識を可能とし, 化学・生物プロセスで威力を発揮す るもととなっている。 分子ユニット間に㗢く力の種類

(1) 共有結合・ $500 \mathrm{~kJ} / \mathrm{mol}$ 程度 
（2）強い相互作用

イオン相互作用

水素結合・・10 $50 \mathrm{~kJ} / \mathrm{mol}$

電荷移動相互作用

$$
\text { など }
$$

(3) 弱い相互作用

双極子一双極子相互作用

ファンデアワールスカ・・1 kJ/mol 程度 など

筆者らは,「異種分子間に働く相互作用を用いた液晶 分子デザインの可能性」に着目し, 選択的水素結合によ り複数種の分子を集合させ, 液晶という秩序状態をつく る新しい手法を見いだした。そして, 一群の新しい夕イ プの水素結合型液晶を構築してきた ${ }^{6) \sim 23) 。 ~}$

Fig. - 1 に示す構造は, 筆者らの研究において最初に 見いだした水素結合型液晶の例である ${ }^{10)}$ 。それぞれ, 160 ${ }^{\circ} \mathrm{C}, 213{ }^{\circ} \mathrm{C}$ まで液晶性を示す安息香酸誘導体とスチルバ ゾール誘導体の間に定量的に形成する水素結合により $238^{\circ} \mathrm{C}$ まで安定な液晶性を示すメソゲン構造 (1) が得ら れた。この場合は水素結合が液晶の安定化に本質的に寄 与している。

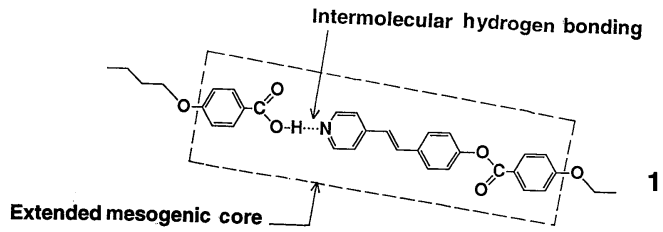

$\begin{array}{lllllll}K & 136 & S_{A} & 160 & N & 238 & I\end{array}$

Fig. -1 Structure of liquid-crystalline hydrogen-bonded complex (1).

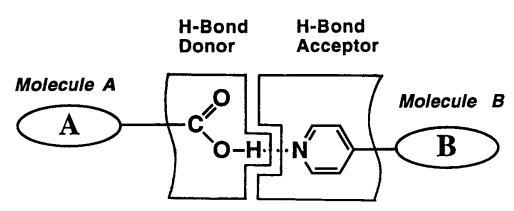

$$
\begin{aligned}
& \text { Selective } \\
& \text { Directional } \\
& \text { Stable } \\
& \text { Dynamic }
\end{aligned}
$$

Fig. -2 The formation of a molecular complex by the $\mathrm{H}$-bonding between carboxylic acid and pyridyl moieties.

水素結合型液晶においては, カルボキシル基・ピリジ ル基間に形成される水素結合により定量的・選択的に分 子を接続し, ある明確な構造を有する分子複合構造を組 み立てることができる(Fig.-2)。これは先ほどの安息 香酸の二量体化とは質が異なるものである。安息香酸に おいては同種分子の二量体構造が基本であり, 単量体分 子が独立に安定に存在することはできない。これに対し て筆者らの系は, 独立に存在する分子間の選択的相互作 用, すなわち分子認識によって成り立っている。した がって, 構造に発展性があり, 多様な分子設計・機能材 料化を行うことができる。

\section{2 水素結合による分子集合構造制御と ダイナミクス}

\section{$2 \cdot 1$ 水素結合とダイナミクス}

それでは，水素結合によって分子を接続することと， 共有結合によるそれの違いは何だろうか。それはまず, そのダイナミクスにある。共有結合でつないだ分子ユ ニットはその結合エネルギーの大きさから結合の切断は

\section{H-Bond Donor}
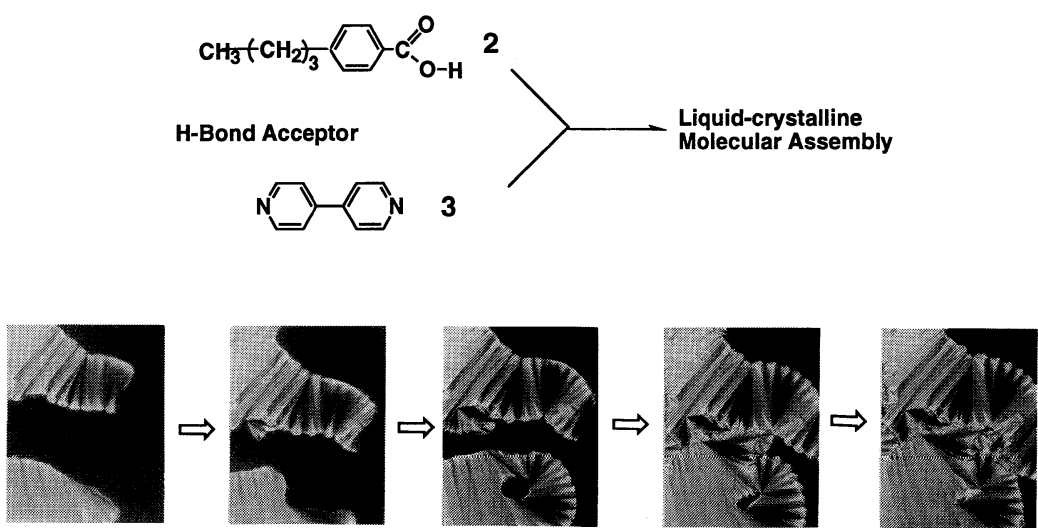

Fig. - 3 Photomicrographs of the process of the formation of H-bonded liquid-crystalline complex (4) by mixing of 4-butylbenzoic acid (2) and $4,4^{\prime}$-bipyridine (3) at $120^{\circ} \mathrm{C}$. 
容易でない。しかし, 水素結合により分子構造を構筑す ると結合の切断・再形成が制御できるという特徴があ る。これが分子のダイナミック（動的）な機能発現を可 能にする。たとえば, DNA・RNA は塩基間の水素結 合によりコンプレックス化し, 二重らせん構造を形成す る。同様な立体構造の形成は共有結合のみによっても可 能であろう。しかし, 遺伝情報が他へ伝達されるために は, 結合の形成・解離が制御されなければならない。ま た, 水素結合性分子凝集系では水が流動性を示すよう に, 水素結合の組み替えが定常的に起きる動的状態をと ることができる。これらは非共有結合によってしか成し えず, 共有結合による構造構築と本質的に異なる点であ る。

本稿では，下に示すような水素結合のダイナミックな 特徵を生かして “超分子集合体の構築” をめざすという 観点から, 水素結合による新しい液晶材料への試みを中 心に述べる。

水素結合の動的特性

(1) 自発的な複合構造・集合構造の形成

(2) 動的状態（結合のスイッチング）

(3) 形成・切断の可逆性

$2 \cdot 2$ ダイナミックな液晶性分子複合体の形成

水素結合型液晶における自発的・動的な分子集合構造 の形成を直接観察することができた。その様子を Fig.3 に示す。ここでは，4-ブチル安息香酸( 2 )を水素結 合ドナーとして，4,4'-ビピリジン( 3 ) を水素結合アク セプターとしてコンプレックス化に用いてある ${ }^{11), 12) 。 ~}$

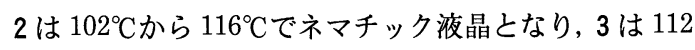
${ }^{\circ} \mathrm{C}$ で融解するが全く液晶性は示さない。この二種の分子

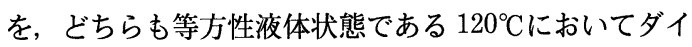
レクトに接触・混合してから偏光顕微鏡下で約 $20 \mathrm{~s}$ お きに撮影した。スメクチックA相の発現に由来するファ ン組織の発達がとらえられている。ここで起きているこ とは，非秩序状態にあったそれぞれの分子が互いを水素 結合により認識して定量的に構造を組み替え, 新しい分 子複合構造 $(4)$ を形成し, 液晶性分子集合状態となる動 的なプロセスである (Fig. -4$) 。$

\section{$2 \cdot 3$ 液晶性ネットワーク構造}

さらに最近, 筆者らは水素結合の動的な特性が本質的 に液晶性の発現に関与する, 新しい夕イプの水素結合 ネットワーク構造を構筑することに成功した ${ }^{13)}$ 。

側鎖にスペーサーを介して安息香酸ユニットを有する ポリアクリレートなどと低分子スチルバゾール誘導体間 の水素結合形成により, 側鎖型高分子液晶構造が得られ

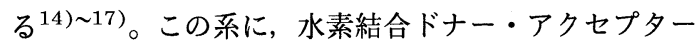
のモル比 $1: 1$ を保ちながら, 4,4'-ビピリジンを加えて いき, 水素結合橋かけ構造を有する高分子コンプレック ス構造( 5 )(Fig.-5)を作製した ${ }^{13)}$ 。その液晶性と橋か け密度の関係を Fig. -6 に示す。この相図において, 横軸 $x$ は全ピリジル基のモル数に対してビピリジンの 2 つのアクセプター基のモル数の割合である。驚くべきこ とに, 2 官能性のビピリジンが増えて橋かけ構造の密度 が上昇しても液晶性は失われず, $100 \%$ 橋かけ構造のコ ンプレックス $(5: x=1.0)$ も $85^{\circ} \mathrm{C}$ から $205^{\circ} \mathrm{C}$ まで夜晶性を

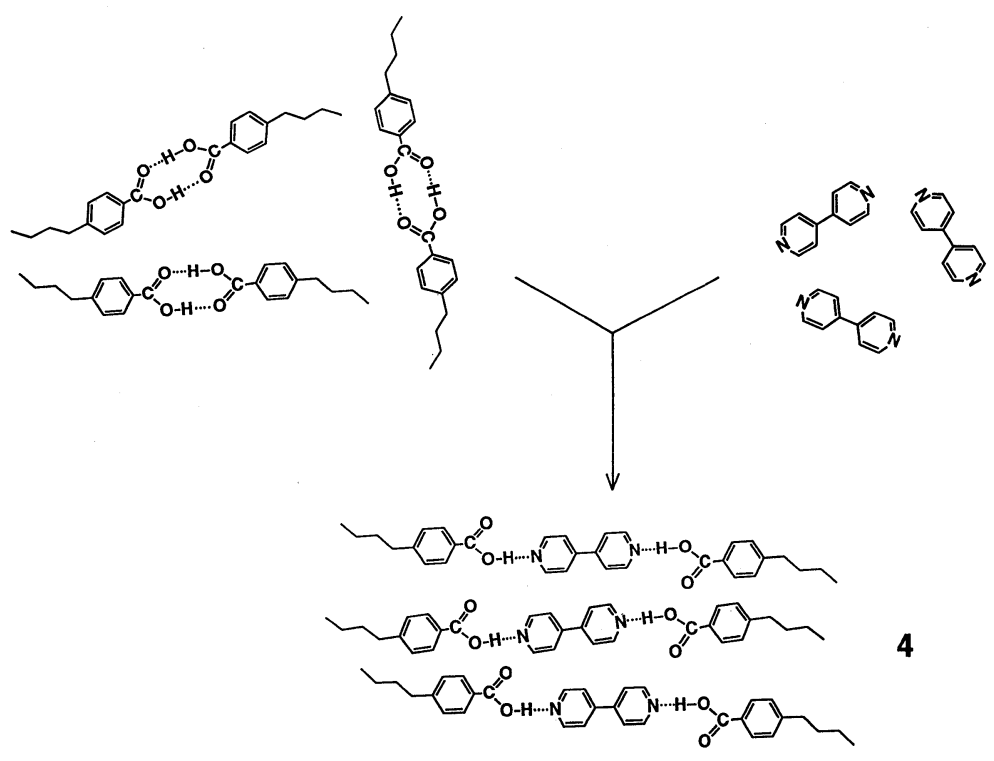

Fig.-4 Schematic illustration of molecular self-assembly of mesogenic hydrogen-bonded complex (4) through selective recognition between $\mathrm{H}-$ bonding donor and acceptor moieties. 


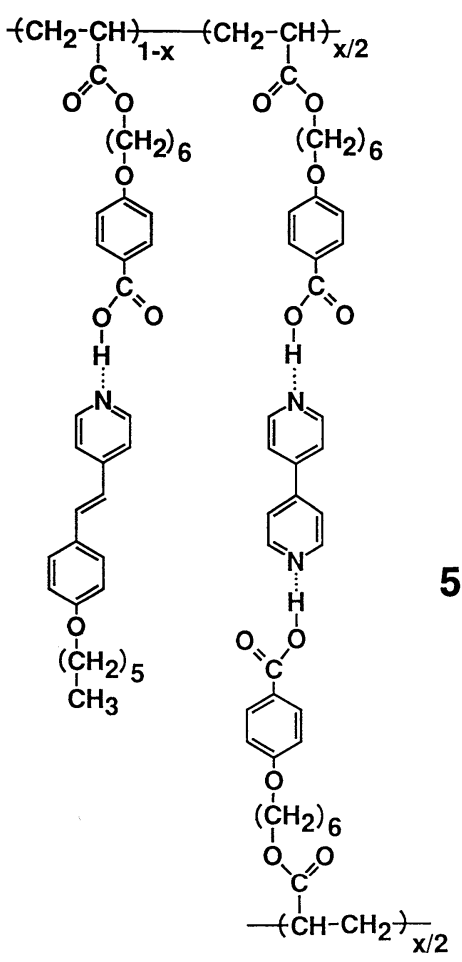

Fig.-5 Molecular structure of $\mathrm{H}$-bonded crosslinked liquid-crystalline polymeric complex (5).

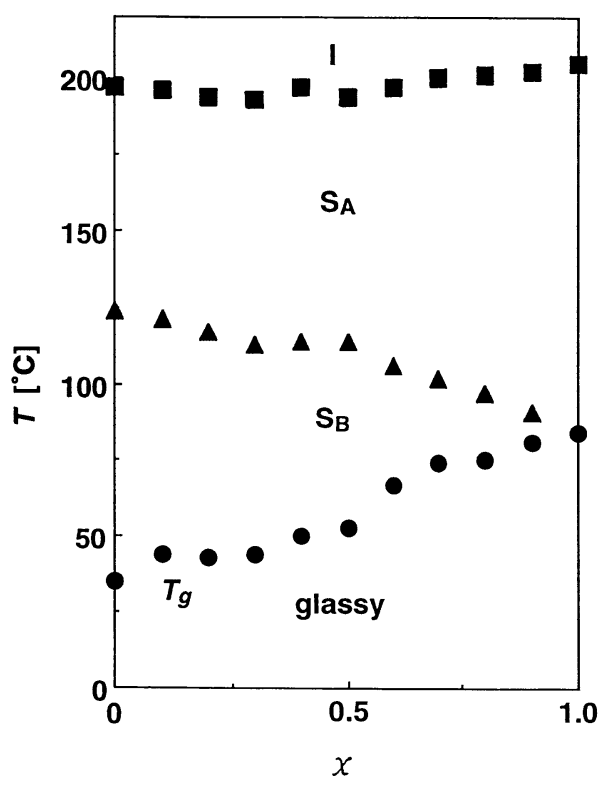

Fig. -6 Phase diagram of the polymeric complexes of 5 .

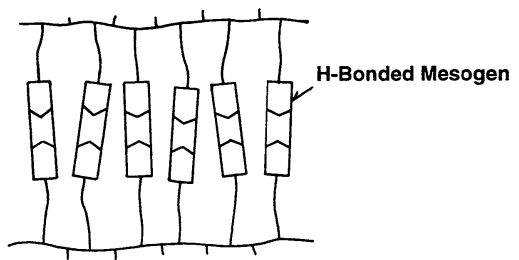

Fig.-7 Schematic illustration of the liquid-crystalline $\mathrm{H}$-bonded network structure ( 5 : $\mathrm{x}=1.0$ ) obtained by self-assembly of a side-chain polymer and a bifunctional compound.

発現した。この液晶相においてはスメクチック相に特有 のフォーカルコニックファン組織が観察された。この状 態においては, 粘性は高いが流動性が見られた。X線測 定の結果, この液晶状態はスメクチック $\mathrm{A}$ 相であった。

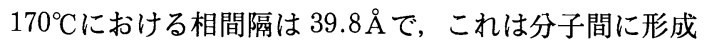
される水素結合構造の伸びきった長さ $41 \AA$ とほぼ等し い。したがって, Fig.-7 に示す分子間メソゲンを有す るネットワーク構造を形成していることがわかった。こ の構造においては水素結合のダイナミクス, すなわち速 い組み替えが定常的に起きていることにより系の流動性 が保たれ，それが液晶性発現と本質的にかかわっている と考えられる。

さらに, この液晶性ネットワークは昇温・降温を繰り 返すと, 液晶状態と等方性液体状態を可逆的に示した。 このことは, 相転移時に水素結合の可逆的な形成・切断 が起こっていることを示唆している。これは, 共有結合

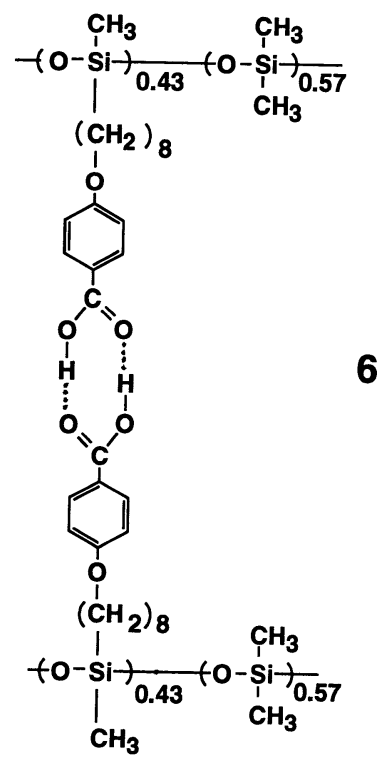




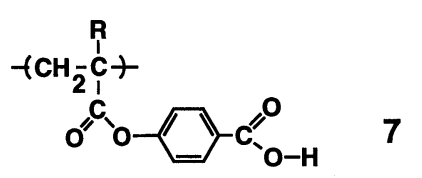

$\mathrm{R}=\mathrm{H}, \mathrm{CH}_{3}$

100\% 橋かけ体では起こりえない挙動である。

上で述べた例は異種分子の分子認識によるネットワー ク構造形成であるが, 上で用いたような水素結合ドナー ポリマー単独でも, ネットワーク液晶構造を形成するこ とも明らかにした ${ }^{14), 15) 。 ホ ゚ リ シ ロ キ サ ン(~} 6$ )は, $10^{\circ} \mathrm{C}$ から $133^{\circ} \mathrm{C}$ までスメクチック C液晶相を分子側鎖間の二 量体化により示した ${ }^{15)}$ 。側鎖に安息香酸ユニットを導 入した高分子は, Blumstein によりすでに7のような ポリアクリレート・ポリメタクリレートについて固体構 造が調べられている ${ }^{24)}$ 。しかし，7 はスペーサーが導 入されていないため系が剛すぎ, 層状の結晶構造を形成 したが, 液晶性は示さなかった。

液晶ポリマーの共有結合による橋かけ構造形成につい

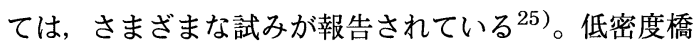
かけの場合は液晶エラストマー化, 高密度橋かけは配向 構造固定の観点から研究が行われている。ここで, 多官 能の液晶性モノマーの重合により得られる共有結合性高 密度三次元橋かけ体は, 不溶・不融の材料となり, 液晶 の分子配向を保持することはできるが液晶状態そのもの は示さない。したがって, 高密度な橋かけ構造を有しな がら液晶性を示す水素結合ネットワークは, これまでに ない新しい夕イプの材料といえる。

水素結合ネットワーク構造を有する液晶性ポリマーブ レンドも構築することができた ${ }^{18)}$ 。水素結合アクセプ ターであるピリジル基を主鎖型高分子の液晶性ポリエス テル(8)の置換基として導入した。そして, 水素結合ド ナー性高分子として機能するポリビニルフェノール(9) との, ポリマーブレンド(Fig.-8)を作製した。このブ

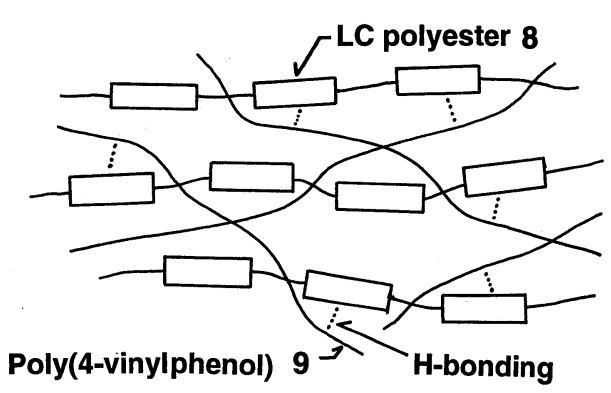

Fig.-9 Schematic illustration of liquid-crystalline polymer blends having $\mathrm{H}$-bonded network structure.

レンドの液晶性を調べたところ, 相分離は観察されず, 均一で安定な液晶性が見られた。これは分子間水素結合 により相溶性が増したためと考えられる。8 単独では 88 ${ }^{\circ} \mathrm{C}$ にガラス転移点 $\left(T_{g}\right)$ があり $175^{\circ} \mathrm{C}$ までネマチック 液晶相を示す。これと $9\left(T_{g}: 138^{\circ} \mathrm{C}\right)$ のドナー・アク セプター比 $1: 1$ のブレンドは, $95^{\circ} \mathrm{C} ら ~ 148^{\circ} \mathrm{C}$ まで通 常より粘性は高いが流動性のあるネマチック液晶相を示 した。この場合, Fig. -9 のうな, 水素結合による分 子配向性ネットワーク構造が形成され，そのダイナミク スにより液晶性が発現していると考えている。これは新 しい構造の分子配向性ポリマーアロイである。

\section{$2 \cdot 4$ 液晶性一次元ポリマー構造}

主鎖型高分子構造を有する液晶性コンプレックスが, 筆者らの水素結合による分子接続の手法を用い, 二官能 性水素結合ドナー・アクセプター同士の組み合わせによ り作製された ${ }^{26)}$ 。ジカルボン酸とビピリジンを一次元

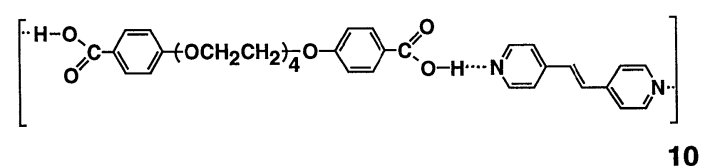

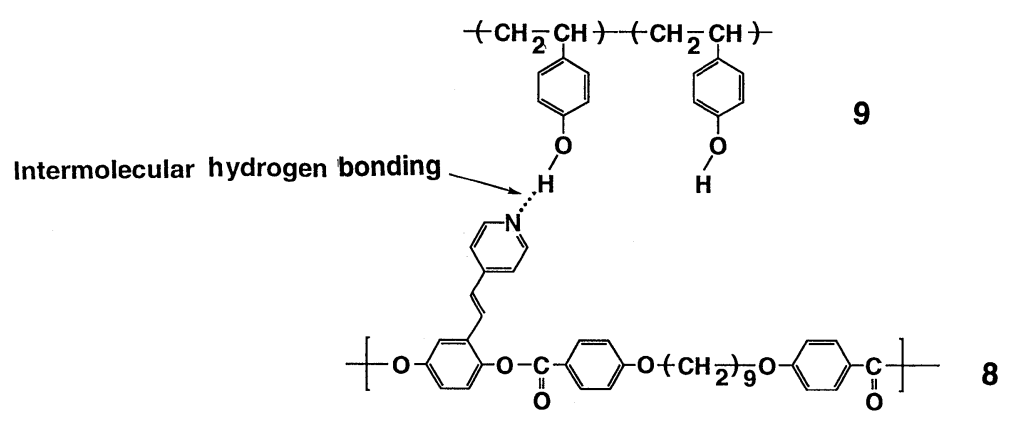

Fig.-8 Molecular structure of a liquid-crystalline polymer blend consisting of polyester (6) having a pyridyl group and poly(4-vinyl phenol)(7). 
的につないだ 1: 1 コンプレックス(10)は, 昇温時には ネマチック相 $\left(178 \sim 183^{\circ} \mathrm{C}\right)$ を, 降温時にはネマチック相 $\left(180 \sim 174^{\circ} \mathrm{C}\right)$, スメクチック相 $\left(174 \sim 164^{\circ} \mathrm{C}\right)$ を示し た。この場合, 液晶状態においては, かなりの程度の” 分子量”を有する高分子コンプレックスが形成している と考えられる。このコンプレックスが, $180^{\circ} \mathrm{C}$ 程度の比 較的低い温度で融解し液晶性を示したことは, オキシエ チレンという柔らかいスペーサーが導入されていること に加え，水素結合のダイナミクスが大きく関与している と考えられる。

水素結合型液晶においては, 液晶という配向した分子 凝集状態で, 水素結合が分子配向場の効果により安定化 を受け, 液晶一等方性液体相転移温度 $\left(T_{i}\right)$ がより高温側 にシフトする。そして $T_{i}$ 以上, すなわち安定化効果が なくなって初めて水素結合が切れていく11),12),19)。こ れは, モデル計算の結果とも一致した ${ }^{27) 。 ~}$

それでは, 希薄溶液状態で, この水素結合相互作用の 安定性やダイナミクスはどうなるだろうか。たとえば, 10 のような主鎖型高分子構造コンプレックスが, 通常 の高分子溶液のような挙動を見せるかは興味の深いとこ ろであるが, 現在のところ水素結合による高分子的物性 は観察されていないようである ${ }^{27) 。 ~}$

Lehn らは, ウラシル基・2,6-ジアミノピリジル基を 有する二官能性の分子間の水素結合相互作用により液晶 性を示す高分子コンプレックス (11) を構筑した ${ }^{28), 29) 。 ~}$ ここで, 酒石酸ユニットにキラル体を用いると, 三重の ヘリックス構造が形成し, それが $250^{\circ} \mathrm{C}$ 程度まで安定な 液晶相を示す。最近, これらの分子複合体に関して電子 顕微鏡による直接観察が行われ，コンプレックス化によ る繊維状の分子集合構造形成がとらえられている30)。 コンプレックス (11) を形成する二種の分子コンポーネ ントの等モル混合物を, クロロホルムに溶解し, 溶液を 蒸発させたサンプルが調べられた。濃度 $50 \mu \mathrm{g} / \mathrm{mL}$ 以 下から調製したものでは小さい粒状の構造しか見られな かったが, それ以上になると縬維状の集合体が現れ, 濃 度がさらに増すとその瀻維状集合体が束になって二次元 的に集合した構造が見られた。

\section{5 分子の多量体複合化による液晶性の発現}

核酸の構成要素である, ヌクレオチド (12) が水素結 合により集合し, リオトロピック液晶相を形成すること が報告されている31) 33)。12 は, 水溶液中で濃度が 2.5 \%から $18 \%$ まではコレステリック相, $18 \%$ から $65 \%$ まではへキサゴナル相を示した。この液晶相発現は, Fig.-10に示すように分子間水素結合により四量体が 形成して, それがカラム状に積み重なるためであること がわかった。現在は, サーモトロピック液晶全盛であ る。しかし, 生体はリオトロピック液晶相と密接な関係 があり, バイオミメティック材料として, このような系<smiles>COP(=O)(O)O[C@H]1C[C@@H]2O[C@H]1CN2n1cnc2c(=O)[nH]c(N)nc21</smiles>

12

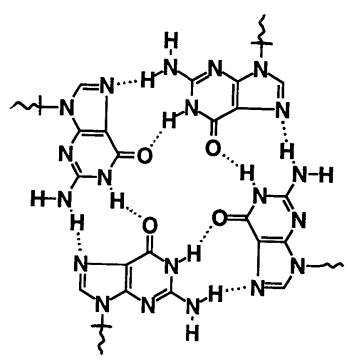

Fig.-10 Tetrameric arrangement of guanine bases of 12 by hydrogen bonding.

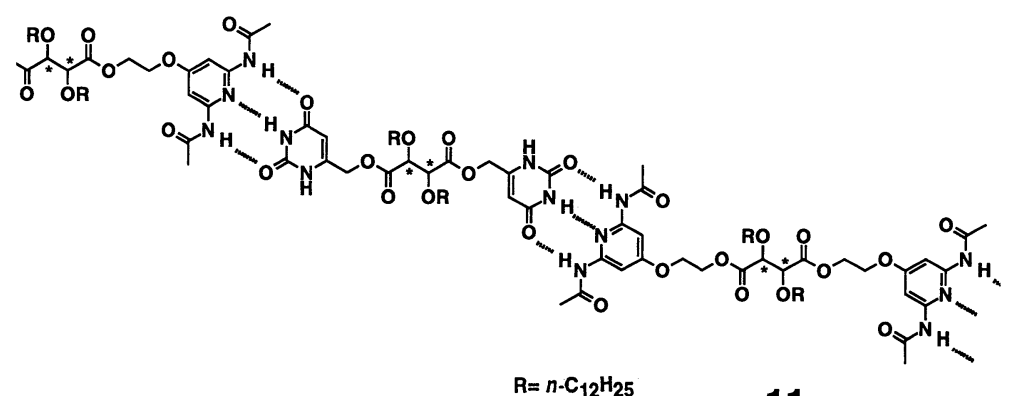

$\mathrm{R}=n-\mathrm{C}_{12} \mathrm{H}_{25}$ 
の構造・機能を見直すと面白そうである。

長鎖アルキル基により化学修飾したアデニンやチミン の単独あるいは混合体が中間相的な状態を経由して, 結 晶状態から等方性液体状態へ変わる可能性が指摘されて (る ${ }^{34)}$ 。キャラクタリゼーションが不充分であるが,

Fig.-11に示すような興味深い分子集合構造の形成も 示唆されており, 今後の進展を待ちたい。

\section{$2 \cdot 6$ 分子配向性ミクロ相分離構造}

液晶ではないが, 水素結合により高分子の集合構造を 制御する試みを一つ紹介する。カルボキシル基・ウラ ゾール基はそれぞれ水素結合により二量化することが知 られている。Stadler は, これらの基を同時に導入した

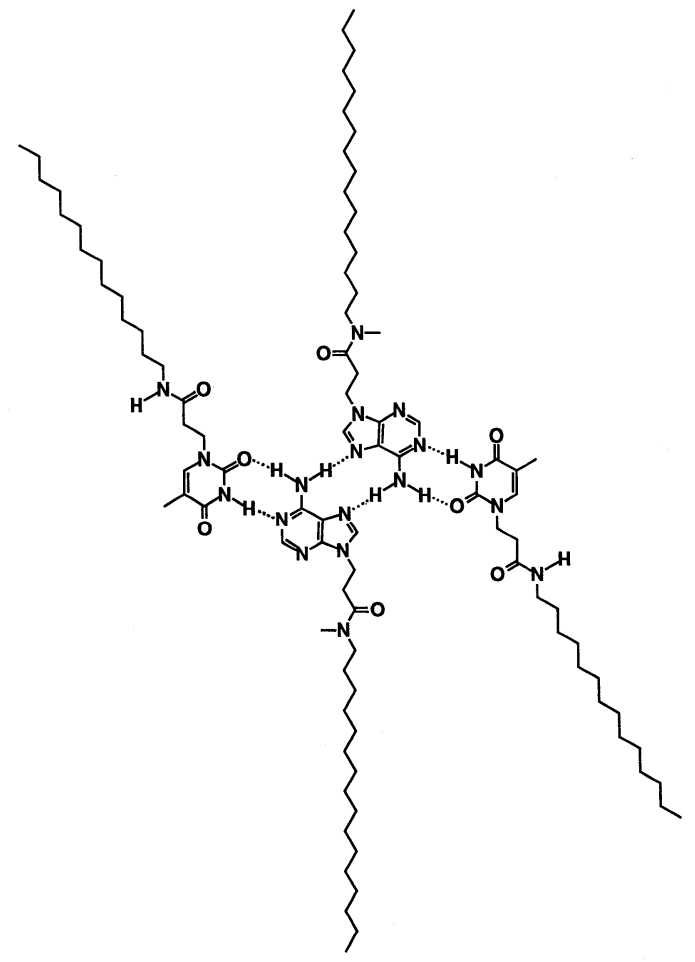

Fig.-11 Association of adenine and thymine nucleobases with long aliphatic chains.
ポリブタジエンを合成した。そして，Fig.-12 のよう な水素結合により高分子側鎖が一次元的につながったコ

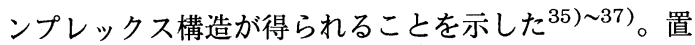
換基のないポリブタジエンの場合は, ガラス転移点が $-98^{\circ} \mathrm{C}$ に見られるのみである。しかし，カルボキシル基 を有するフェニルウラゾール基により $4 \mathrm{~mol} \%$ 修飾し たポリブタジエンは, DSC 測定において昇温時 $80^{\circ} \mathrm{C} に$ 吸熱ピークを示した。また，この温度までは複屈折性が 観察されたがそれ以上に加熱すると複屈折性は失われ， 等方的な液体となった。これは $80^{\circ} \mathrm{C}$ までは水素結合コ ンプレックスが凝集・配向した相とアモルファス相から なる多相構造が形成しているが(Fig.-13), それ以上で はその水素結合が解離して，均一な分子無配向状態にな ることを示している。等方性状態から冷却して熱処理を 行うと, 再び多相構造を再形成する熱的可逆性が観察さ れている。さらにこの系は, 水素結合によりネットワー ク構造となっているとも見ることができ，水素結合によ る高次構造制御の面白い例といえる。

\section{3 おわりに-アクティブな機能性分子 集合材料の構築をめざして}

以上，水素結合による分子認識を用いた集合体構築に ついて, 液晶材料を主に述べてきた。構造が水素結合の

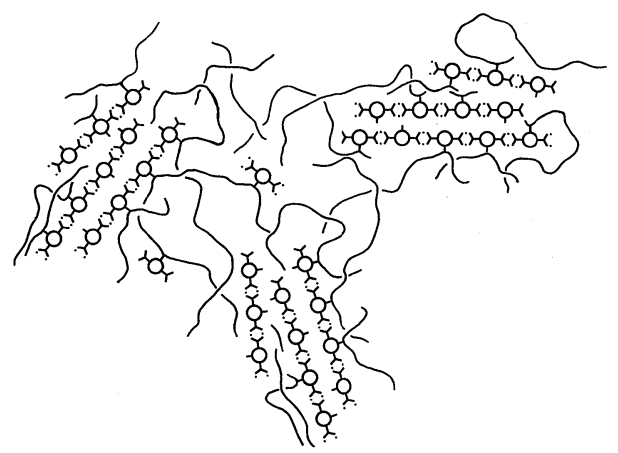

Fig. -13 Schematic illustration of the aggregated side-chain of polymers.

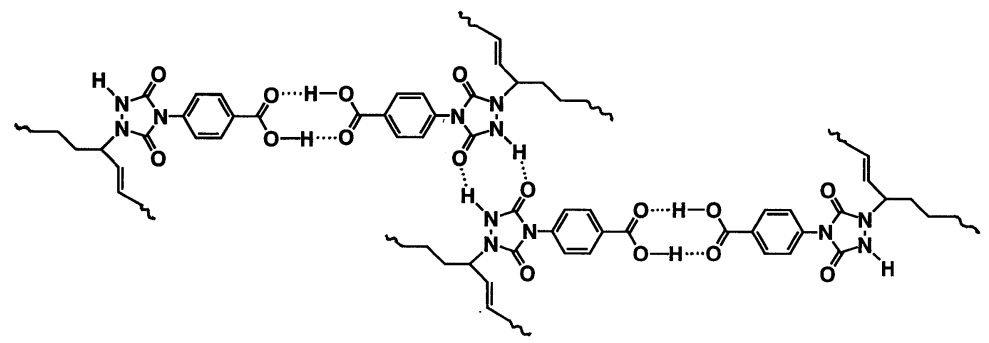

Fig.-12 Association of 4-carboxyphenylurazole in the side-chain of polybutadiene by hydrogen bonding. 
ような非共有結合により分子複合化したものであると， そのダイナミクスにより構造の組み替え・変化が可能で ある。すなわち分子がより生きている状態に近い状態に おかれるといえる。したがって, 環境・外部刺激に対し てアクティブに応答するような新しいインテリジェント 材料にすることが可能ではないかと考えている。

本稿では述べられなかったが, 近年, 結晶構造制御 ${ }^{4)}$ あるいは界面における分子認識に ${ }^{38), 39), ~}$ 水素結合を用 いていく試みも活発になってきている。分子集合体にお いて, さまざまな相互作用を精密に制御して $\left.{ }^{40)}, 41\right)$, 超 分子機能材料構築することが今後大きく発展し, 従来の 概念を越えた全く新しい分子材料に発展することを期待 したい。

[平成 6 年 (1994 年) 5 月 9 日受理]

\section{文献}

1） J.N. Israelachvili，(近藤 保, 大島広行訳), “分子間 カと表面力”, マグロウヒル (1991)

2) M.D. Joesten, L.J. Schaad, "Hydrogen Bonding", Dekker (1974)

3）たとえば, J.M. Lehn, Angew. Chem. Int. Ed. En$g l ., \quad 27,89(1988)$

4) たとえば, M. C. Etter, Acc. Chem. Res., 23, 120 (1990) ; J.M. Lehn, Angew. Chem. Int. Ed. Engl., 29, 1304 (1990)

5) A.E. Bradfield, B. Jones, J. Chem. Soc., 1929, 2660 ; G.W. Gray, B. Jones, J. Chem. Soc., 1953, 4179

6) 加藤隆史, 化学と工業, 45, 269 (1992)

7) 加藤隆史, 表面, 31, 221 (1993)

8）加藤隆史，高分子， 42, 672 (1993)

9) 加藤隆史, 染料と薬品, 38, 324 (1993)

10) T. Kato, J.M.J. Fréchet, J. Am. Chem. Soc., 111, 8533 (1989)

11) T. Kato, P.G. Wilson, A. Fujishima, J.M.J. Frechet, Chem. Lett., 1990, 2003

12) T. Kato, J.M.J. Fréchet, P.G. Wilson, T. Saito, T. Uryu, A. Fujishima, C. Jin, F. Kaneuchi, Chem. Mater., 5, 1094 (1993)

13) T. Kato, H.Kihara, U. Kumar, A. Fujishima, T. Uryu, J.M.J. Fréchet, Polym. Prep., Div. Polym. Chem., Am. Chem. Soc., 34 (2), 722 (1993) ; Angew. Chem. Int. Ed. Engl., 33, 1646 (1994)

14) T. Kato, J.M.J. Frechet, Macromolecules, 22, 3818 (1989)

15) U. Kumar, T. Kato, J. M. J. Frechet, J. Am. Chem. Soc., 114, 6630 (1992)

16) T. Kato, H. Kihara, T. Uryu, A. Fujishima, J.M.J. Fréchet, Macromolecules, 25, 6836 (1992); T. Kato, H. Adachi, N. Hirota, A. Fujishima, J.M.J. Fréchet, Contem. Top. Polym. Sci., 7, 299 (1992)
17) U. Kumar, J.M.J. Fréchet, T. Kato, S. Ujiie, K. Iimura, Angew. Chem. Int. Ed. Engl., 31, 1531 (1992)

18）佐藤晶子, 加藤隆史, 瓜生敏之, 高分子学会予稿集, 41, 883 (1992) ; 41, 3638 (1992)

19) T. Kato, T. Uryu, F. Kaneuchi, C. Jin, J. M.J. Fréchet, Liq. Cryst., 14, 1311 (1993)

20) T. Kato, A. Fujishima, J.M.J. Fréchet, Chem. Lett., 1990, 919

21) T. Kato, H. Adachi, A. Fujishima, J.M.J. Fréchet, Chem. Lett., 1992, 265

22) T. Fukumasa, T. Kato, T. Uryu, J.M.J. Fréchet, Chem.Lett., 1993, 65

23) T.Kato, H. Kihara, T. Uryu, S. Ujiie, K. Iimura, U. Kumar, J.M.J. Fréchet, Ferroelectrics, 148, 161 (1993)

24) A.Blumstein, S.B. Clough, L. Patel, R.B. Blumstein, E.C. Hsu, Macromolecules, 9, 243 (1976)

25）たとえば, J. Kupfer, H. Finkelmann, Makromol. Chem., Rapid Commun., 12, 717 (1991) ; F.J. Davis, J. Mater. Chem., 3, 551 (1993) ; R. Zentel, Angew. Chem. Adv.Mater., 101, 1437 (1989)

26) C. Alexander, C.P. Jariwala, C. -M. Lee, A.C. Griffin, Polymer Preprints, 34(1), 168 (1993)

27) P. Bladon, A.C. Griffin, Macromolecules, 26, 6604 (1993)

28) C. Fouquey, J.-M. Lehn, A.-M. Levelut, $A d v$. Mater., 2, 254 (1990)

29) J.-M. Lehn, Makromol. Chem. Macromol. Symp., 69, 1 (1993)

30) T. Gulik-Krzywicki, C. Fouquey, J.-M. Lehn, Proc. Natl. Acad. Sci. U.S.A., 90, 163 (1993)

31) S. Bonzanni, M.M. DeMorais, G. Gottarelli, P.Mariani, G.P. Spada, Angew. Chem. Int. Ed. Engl., 32, 248 (1993)

32) P. Mariani, C. Mazabard, A. Garbesi, G.P. Spada, J. Am. Chem. Soc., 111, 6369 (1989)

33) S. Bonzanni, M. Capobianco, M.M. DeMorais, A. Garbesi, G. Gottarelli, P. Mariani, M.G.P. Bossi, G.P. Spada, L. Tondelli, J. Am. Chem. Soc., 113, 5809 (1991)

34) C.M. Paleos, J. Michas, Liq. Cryst., 11, 773 (1992)

35) C. Hilger, R. Stadler, Macromolecules, 23, 2097 (1990)

36) C. Hilger, R. Stadler, Makromol. Chem., 192, 805 (1991)

37) C. Hilger, M. Drager, R. Stadler, Macromolecules, 25, 2498 (1992)

38) M. Ahlers, W. Muller, A. Reichert, H. Ringsdorf, J. Venzmer, Angew. Chem. Int. Ed. Engl., 29, 1269 (1990)

39) Y. Honda, K. Kurihara, T. Kunitake, Chem. Lett., 1991, 681

40）加藤隆史, 日本写真学会誌, 55, 73 (1992)

41）加藤隆史, 生産研究, 46, 313 (1994) 